\title{
OBSERVATIONS ON AFRICAN CHILDREN
}

\author{
BY \\ E. A. BEET \\ From the Colonial Medical Service, Northern Rhodesia
}

(Received for Publcation April 17, 1950)

In a previous publication an account was given of the haemoglobin values found in school children of a Bantu tribe, the Lala, resident in the central province of Northern Rhodesia (Beet, 1949). This paper records the results of a more detailed health survey carried out on the same group of children, the previous investigation being part of the whole survey. The work took place in the field during the period November, 1947, to December, 1948.

The Lala live in the Serenje district of Northern Rhodesia, probably having migrated there over 100 years ago from the Belgian Congo. They are a matrilineal, matrilocal tribe, the women of the villages playing a very important part in the daily lives of the people. As the railway is only 180 miles away from the Government station at Serenje, a large proportion of the men are away from home at any one time working in the copper mines and other industries. For this reason it was considered advisable to concentrate on the children, most of whom would be too young to have been away from their homeland.

The object of this survey was to obtain a general clinical picture of a group of rural African children living at home in the reserves under natural conditions. The results show how a group of children have reacted to their natural environment. Also it is hoped that this survey will be a basis for comparison with other workers' results whose subjects have lived under different environmental conditions.

\section{The Lak Country}

The sketch map shows the distribution of the schools visited. The Lala country occupies the whole of the administrative district of Serenje and the eastern half of Mkushi; both of these districts are in the Central Province of Northern Rhodesia, the provincial centre of which is at Broken Hill on the railway.

Two distinct types of country are found, the plateau and the valley areas.

The Phatean Area. The majority of the Lala live in the highlands of the Serenje and Mkushi Districts at an altitude ranging from 3,500 to 5,000 ft. The
Government station at Serenje is $4,687 \mathrm{ft}$. and that at Mkushi 3,711 ft. above sea level.

The Great North Road (Cape Town to Nairobi) runs through this area, and in Serenje follows the Zambesi-Congo watershed. To the north of the road the drainage is through the Luapula and Congo River systems to the Atlantic Ocean and to the south through the Luangwa-Zambesi systems to the Indian Ocean.

Brachystegia-Isoberlinia woodland covers the plateau area, being interspersed with treeless plains (known as dambos) which follow the course of some of the streams. Surface water is usually plentiful and the majority of the larger streams flow throughout the year. The country is undulating in the vicinity of the watershed but to the south becomes hilly and near the escarpment is mountainous.

The Valley Area. To the east of the plateau the country is quite different. Here the altitude is only 1,500-2,500 ft. above sea level. Through this lowlying area run the Lukusashi, Luangwa, and Lunsemfwa rivers which receive the streams and rivers arising on the Zambesi side of the ZambesiCongo watershed. The Lukusashi itself rises in the highlands of Serenje. Mupane woodland is predominant in the valley area. The big rivers such as the Luangwa, Lukusashi, Kaombe, and Lunsemfwa flow all the year round, but the small streams which originate in the valley and escarpment zones are dry in the dry season, thus accounting for the concentration of the population along the banks of the major rivers. The valley is infested with tsetse fly but no cases of human trypanosomiasis have been reported.

The valley is separated from the plateau by a well-defined escarpment, the plateau side of the escarpment being very hilly and for the most part uninhabited.

\section{The Climate}

On the plateau the climate is very pleasant all the year round; in the cold dry season frosts are not uncommon. Table 1 shows the monthly rainfall and temperature figures for the Government station at Serenje for 1948. 


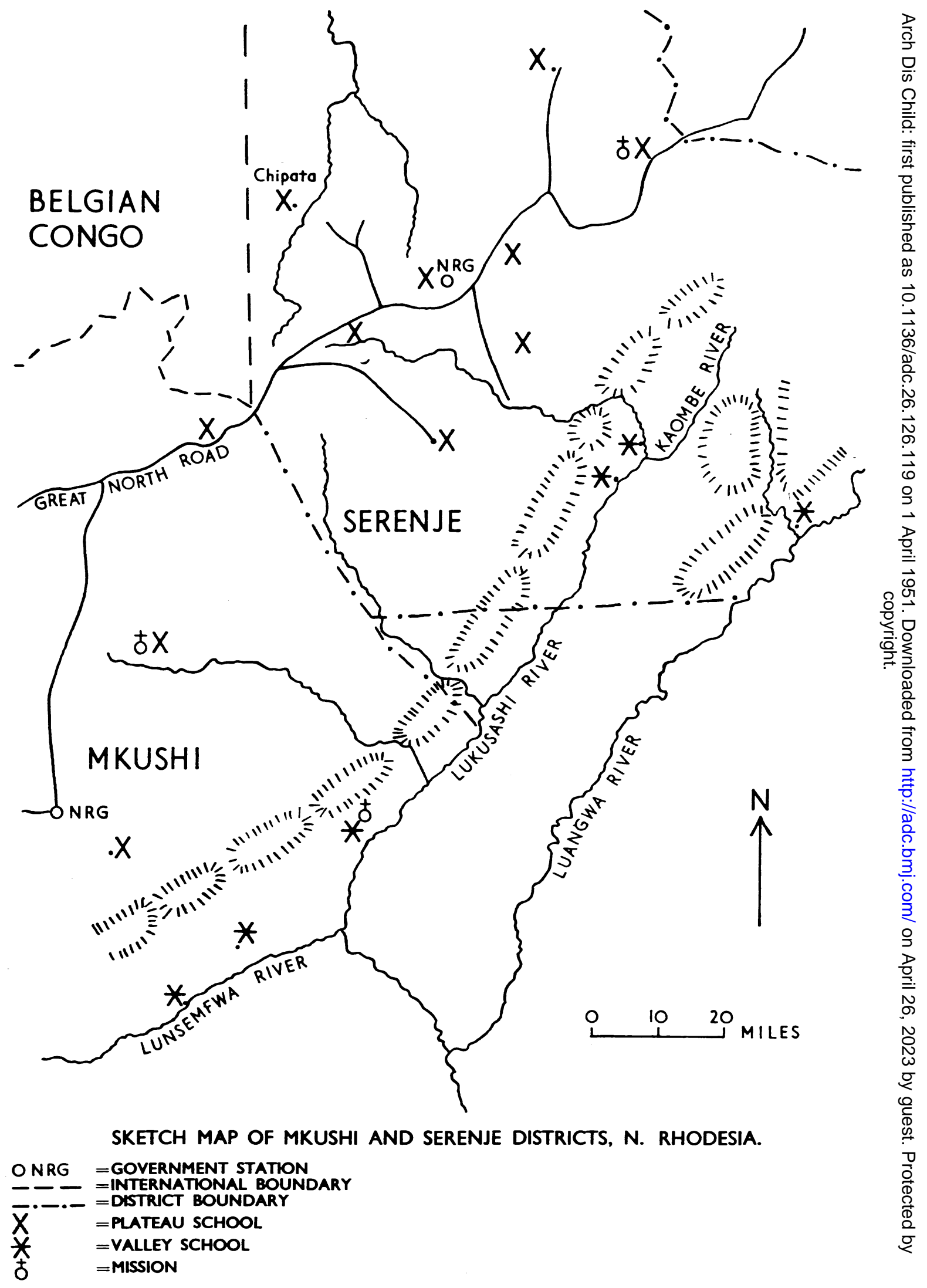


TABLE 1

Rainfall and Temperature at Serenje, 1948

\begin{tabular}{|c|c|c|c|c|}
\hline \multirow{2}{*}{\multicolumn{2}{|c|}{ Month }} & \multirow[b]{2}{*}{$\begin{array}{l}\text { Rainfall } \\
\text { (in.) }\end{array}$} & \multicolumn{2}{|c|}{ Temperature $\left({ }^{\circ} \mathrm{F}.\right)$} \\
\hline & & & $\underset{\text { Maximum }}{\text { Mean }}$ & $\begin{array}{c}\text { Mean } \\
\text { Minimum }\end{array}$ \\
\hline $\begin{array}{l}\text { January } \\
\text { February } \\
\text { March } \\
\text { April } \\
\text { May } \\
\text { June } \\
\text { July } \\
\text { August } \\
\text { September } \\
\text { October } \\
\text { November } \\
\text { December }\end{array}$ & $\begin{array}{l}. . \\
. \\
. \\
. \\
. \\
. \\
\because \\
\because \\
\cdots \\
\cdots \\
.\end{array}$ & $\begin{array}{c}12 \cdot 10 \\
9 \cdot 32 \\
9 \cdot 89 \\
1 \cdot 41 \\
0 \cdot 01 \\
0 \cdot 05 \\
0 \cdot 01 \\
= \\
\overline{-} \\
0 \cdot 44 \\
3 \cdot 98 \\
7 \cdot 00\end{array}$ & $\begin{array}{l}75 \\
76 \\
76 \\
75 \\
74 \\
70 \\
70 \\
72 \\
79 \\
84 \\
81 \\
79\end{array}$ & $\begin{array}{l}59 \\
61 \\
63 \\
66 \\
59 \\
49 \\
49 \\
52 \\
54 \\
61 \\
62 \\
61\end{array}$ \\
\hline Total & $\ldots$ & $44 \cdot 21$ & & \\
\hline
\end{tabular}

There is a well-defined rainy season when all crops have to be planted. The rains were good during 1948, and the figures recorded are probably over the average.

Temperatures are much higher in the valley, and during the hot months of October and November the weather is very unpleasant day and night. There are no figures available for comparison with the plateau, but that there is a marked difference is shown by the valley people's disinclination to move on to the plateau to settle there owing to the cold: however, the plateau Lala are not infrequently found in the valley as they can adapt themselves to the warmer climate.

\section{Agriculture and Staple Crops}

A detailed account of the agricultural practices of the Lala are given by Trapnell (1943) in his ecological survey of north-eastern Rhodesia. Until recently the staple crop of all the plateau Lala was finger millet which is grown by the southern chitemene system. In this method clearings of woodland, of anything from 16 to 27 acres each year, are cut by a single man, and the cut trees stacked in small heaps which are subsequently burnt about September, well before the onset of the first rain. The millet seed is sown in the burnt patches without preliminary hoeing, the cleared area usually being 15 to 25 times the area actually burnt and planted. As the cleared forest is only used once for the main crop, although it may be used in the following season for catch crops such as beans and ground-nuts, this is a most wasteful method of cultivation and results in the wholesale destruction of trees throughout the Lala country.

The plateau Lala in the Serenje district practise the system just described and their land is suffering accordingly. In the Mkushi District, however, the plateau Lala have been prohibited from growing finger millet as a staple crop and limits are laid down of what a single man may cultivate. As a result the staple in Mkushi is now kaffir corn which is cultivated on a simple hoe system; millet is still consumed to a small extent but it is probable that most of it is used to make beer, millet beer being considered the best. The valley Lala grow kaffir corn as a staple, on a similar system to that used by the Mkushi plateau Lala, as Mupane woodland is unsuitable for the cultivation of finger millet.

TABLE 2

Average Intake and Estimated Requirement of Nutriment per Head per day for Serenje Plateau Lala AUGUST, 1947 TO JULY, 1948 (ThOMSON, 1949)

\begin{tabular}{|c|c|c|c|c|c|c|c|c|c|c|c|c|c|c|}
\hline 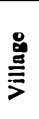 & & Calories & $\begin{array}{l}\text { Total } \\
\text { Protein } \\
\text { (8.) }\end{array}$ & $\begin{array}{c}\text { Animal } \\
\text { Protein } \\
\text { (g.) }\end{array}$ & $\begin{array}{l}\text { Fat } \\
\text { (g.) }\end{array}$ & $\begin{array}{l}\text { Carbon- } \\
\text { hydrates } \\
\text { (g.) }\end{array}$ & $\begin{array}{c}\text { Calcium } \\
\text { (mg.) }\end{array}$ & $\begin{array}{l}\text { Iron } \\
\text { (mg.) }\end{array}$ & $\begin{array}{l}\text { Vitamin } \\
\text { A as } \\
\text { Carotene } \\
\text { (I.U.) }\end{array}$ & $\begin{array}{c}\text { Vitamin } \\
\text { (I.U.) }\end{array}$ & $\begin{array}{c}\text { Aneurin } \\
\text { (mg.) }\end{array}$ & $\begin{array}{l}\text { Ribo- } \\
\text { flavin } \\
\text { (mg.) }\end{array}$ & $\begin{array}{l}\text { Nico- } \\
\text { tinic } \\
\text { Acid } \\
\text { (mg.) }\end{array}$ & $\begin{array}{l}\text { Ascor- } \\
\text { bic } \\
\text { Acid } \\
\text { (mg.) }\end{array}$ \\
\hline \multirow{2}{*}{$\mathbf{A}$} & Intake & 1,392 & $42 \cdot 1$ & $9 \cdot 3$ & $9 \cdot 9$ & 284 & 1,202 & $22 \cdot 7$ & 2,337 & 22 & $1 \cdot 12$ & 0.48 & $7 \cdot 8$ & $15 \cdot 5$ \\
\hline & $\begin{array}{l}\text { Estimated } \\
\text { requirement }\end{array}$ & 2,298 & $63 \cdot 0$ & & & & 984 & $11 \cdot 4$ & 3,210 & & $1 \cdot 29$ & $1 \cdot 61$ & $10 \cdot 8$ & $41 \cdot 8$ \\
\hline \multirow[b]{2}{*}{ B } & Intake & 1,650 & $46 \cdot 5$ & $9 \cdot 2$ & $13 \cdot 1$ & 334 & 1,582 & $29 \cdot 2$ & 4,320 & 0.6 & $1 \cdot 49$ & 0.51 & $9 \cdot 1$ & $14 \cdot 5$ \\
\hline & $\begin{array}{l}\text { Estimated } \\
\text { requirement }\end{array}$ & 2,212 & $60 \cdot 3$ & & & & 936 & $11 \cdot 0$ & 3,062 & & $1 \cdot 19$ & 1.54 & $10 \cdot 3$ & $39 \cdot 5$ \\
\hline \multirow[b]{2}{*}{ C } & Intake & 1,269 & $41 \cdot 2$ & 4.65 & $10 \cdot 4$ & 255 & 931 & $22 \cdot 4$ & 3,094 & 21 & $1 \cdot 30$ & 0.59 & $8 \cdot 9$ & 18 \\
\hline & $\begin{array}{l}\text { Estimated } \\
\text { requirement }\end{array}$ & 2,268 & $60 \cdot 7$ & & & & 916 & $11 \cdot 1$ & 3,132 & & $1 \cdot 17$ & 1.54 & $10 \cdot 4$ & 40 \\
\hline
\end{tabular}

Men, women and children have been grouped together. The average intake has been cakculated from total figures and the estimated requirements from allowances recommended by the S.A. National Nutrition Council, or by the U.S.A. Committee on Foods and Nutrition, using the same age groups as were found when compiling the intake figures.

- Probably underestimated owing to the back of knowledge of vitamin contents of African foodstuffs and of the actual quantities of wild fruits and beer which were consumed. 


\section{The Diet}

While the health survey was in progress a detailed dietary survey of the Serenje plateau was being carried out by Mrs. Thomson, Nutrition Officer to the Northern Rhodesia Government (Thomson, 1949). Three villages were systematically investigated for one year, one week in every four being spent at each village. Table 2 is an extract from Mrs. Thomson's final report and gives an indication of the average intake of nutriment per head per day for each village for the period under survey.

No figures are available for the Mkushi plateau Lala or the valley Lala. The Mkushi plateau Lala have a different staple cereal, kaffir corn instead of finger millet, and also possess cattle, which the Serenje plateau Lala only do occasionally, resulting in a greater consumption of animal food products. Apart from these differences the diets of the two sub-divisions of the plateau are very similar. In addition to the staples, kaffir corn and finger millet, maize and cassava are eaten, and beans, peas, ground-nuts, and pumpkins are grown; wild plants and fruits are also collected. Game is scanty throughout the plateau; chickens are to be found in all villages, but eggs are not as a rule eaten.

The valley people rely on kaffir corn as a staple and do not grow millet, a varying amount of maize being grown according to the kaffir corn crop. As maize grows well on the alluvial banks of the main rivers when the floods go down, it can be planted throughout the dry season after the kaffir corn crop has been garnered. Rice is also grown in favourable years and meat is available to a greater extent than on the plateau owing to the presence of game; cattle cannot be kept because of tsetse fly. Bananas grow well but are in many cases destroyed by elephant. The same types of vegetables are eaten as on the plateau, the banks of the rivers being ideal sites for vegetable gardens. If they wished the valley Lala could live comfortably from the dietary point of view, but owing to the prevailing lethargy, food is often very short; in addition they have to face the hazards resulting from the not infrequent destruction of their crops by hippopotamus, elephant, bush pig, and monkey, various insects, and high floods.

\section{The Present Survey}

Seventeen schools were visited and 660 children examined. Table 3 shows the distribution of the schools and the number of children for each of the three areas.

The plateau schools were all accessible by road or a combination of road and cycle, but the valley schools were all in remote areas and had to be
TABLE 3

Distribution of Schools and ChILdRen

\begin{tabular}{|c|c|c|c|}
\hline \multirow[t]{2}{*}{ Area } & \multirow[t]{2}{*}{$\begin{array}{l}\text { No. of Schools } \\
\text { Visited }\end{array}$} & \multicolumn{2}{|c|}{$\begin{array}{l}\text { No. of Children } \\
\text { Examined }\end{array}$} \\
\hline & & Boys & Girls \\
\hline $\begin{array}{l}\text { Serenje plateau .. } \\
\text { Mkushi plateau .. } \\
\text { Valley }\end{array}$ & $\begin{array}{l}8 \\
3 \\
6\end{array}$ & $\begin{array}{r}219 \\
80 \\
100\end{array}$ & $\begin{array}{r}116 \\
50 \\
95\end{array}$ \\
\hline Total & 17 & 399 & 261 \\
\hline
\end{tabular}

visited on foot with native carriers. The selection of children for examination was haphazard, apart from choosing the younger children from each school.

Examination included (1) height and weight record (on the same machine throughout); (2) clinical examination; (3) haemoglobin determination with Sahli haemoglobinometer; (4) examination of a blood smear stained by Field's stain for malaria and of a sealed wet preparation for the sickle cell trait; (5) examination of the centrifuged deposit of urine for schistosome ova; (6) examination of faeces suspended in a saturated solution of magnesium sulphate for hookworm ova.

In addition 77 samples of sera were examined by the copper sulphate method for plasma proteins (Phillips, 1943), but this investigation was abandoned because the children objected to the discomfort of an intravenous withdrawal of blood and we had to remain as popular as possible to get their full cooperation.

\section{Findings of the Survey}

Plasma Proteins. Table 4 gives the findings for the 77 total plasma protein estimations performed by the copper sulphate specific gravity method. Serum was used in each case.

TABLE 4

Results of 77 Total Plasma Protein Estimations

Mean _.. . 6.91 g. per $100 \mathrm{ml}$.

Standard deviation 0.58 .

Mode $\quad$. $\quad$. $\quad 6.925$ per $100 \mathrm{ml}$. (using groups of Range $\quad$.. $\quad \ldots \quad 5 \cdot 6-8 \cdot 2 \mathrm{~g} \cdot \operatorname{per} 100 \mathrm{ml}$.

Stephen (1948) in the Gold Coast recorded a mean of $7.1 \mathrm{~g}$. per $100 \mathrm{ml}$. for 50 children; Barakat and Dean Smith (1949) review the literature on the subject, as far as it concerns Africa, and give a mean of $7.66 \mathrm{~g}$. per $100 \mathrm{ml}$. for a group of adult Gambian natives. 
TABLE 5

Mean Weights of 629 lala School Children

\begin{tabular}{|c|c|c|c|c|c|c|c|}
\hline \multirow{2}{*}{$\begin{array}{c}\text { Approximate } \\
\text { Age } \\
\text { (years) }\end{array}$} & \multirow{2}{*}{$\begin{array}{l}\text { Height } \\
\text { (in.) }\end{array}$} & \multirow{2}{*}{ Sex } & \multirow{2}{*}{ Numbers } & \multirow{2}{*}{$\begin{array}{l}\text { Mean } \\
\text { Weight } \\
\text { (lb.) }\end{array}$} & \multicolumn{2}{|c|}{ Weight Range (lb.) } & \multirow{2}{*}{$\begin{array}{c}\text { Weight /Height } \\
\text { Ratio }\end{array}$} \\
\hline & & & & & Min. & Max. & \\
\hline \multirow{2}{*}{-8} & \multirow{2}{*}{$\begin{array}{l}45 \cdot 5 \\
-48\end{array}$} & Boys & 15 & $47 \cdot 3$ & $43 \cdot 5$ & $61 \cdot 5$ & $1 \cdot 02$ \\
\hline & & Girls & 14 & $46 \cdot 5$ & $43 \cdot 5$ & $52 \cdot 5$ & $1 \cdot 00$ \\
\hline \multirow{2}{*}{$-9 \frac{1}{2}$} & \multirow{2}{*}{-51} & Boys & 43 & $53 \cdot 8$ & $46 \cdot 5$ & $64 \cdot 5$ & 1.09 \\
\hline & & Girls & 28 & $54 \cdot 3$ & $46 \cdot 5$ & $64 \cdot 5$ & $1 \cdot 10$ \\
\hline \multirow{2}{*}{-11} & \multirow{2}{*}{-54} & Boys & 94 & $61 \cdot 3$ & $52 \cdot 5$ & $73 \cdot 5$ & $1 \cdot 17$ \\
\hline & & Girls & 53 & $59 \cdot 7$ & $49 \cdot 5$ & $70 \cdot 5$ & $1 \cdot 14$ \\
\hline \multirow{2}{*}{$-12 \frac{1}{2}$} & \multirow{2}{*}{-57} & Boys & 110 & $71 \cdot 2$ & $55 \cdot 5$ & $91 \cdot 5$ & $1 \cdot 29$ \\
\hline & & Girls & 72 & $72 \cdot 6$ & $55 \cdot 5$ & $133 \cdot 5$ & $1 \cdot 31$ \\
\hline \multirow{2}{*}{-14} & \multirow{2}{*}{-60} & Boys & 77 & $81 \cdot 3$ & $67 \cdot 5$ & $100 \cdot 5$ & $1 \cdot 39$ \\
\hline & & Girls & 63 & $82 \cdot 8$ & $58 \cdot 5$ & $100 \cdot 5$ & 1.42 \\
\hline \multirow{2}{*}{ Over } & \multirow{2}{*}{-63} & Boys & 33 & $95 \cdot 5$ & $76 \cdot 5$ & $121 \cdot 5$ & $1 \cdot 55$ \\
\hline & & Girls & 27 & $93 \cdot 2$ & $64 \cdot 5$ & $124 \cdot 5$ & $1 \cdot 52$ \\
\hline
\end{tabular}

Heights and Weights. As it was impossible to gauge with any degree of accuracy the ages of the children they have been classified into 3 in. height groups. The mean weight and other details of each height group are shown in Table 5. For the sake of simplicity children over 63 in. in height have been excluded owing to the small number and degree of scatter. Table 5 is based on 629 observations. In the field heights were recorded to the nearest $\frac{1}{4}$ in. and weights to the nearest $\frac{1}{4} \mathrm{lb}$.; when compiling the table, weights were classified in $3 \mathrm{lb}$. groups, means being calculated from the mid-points of the relevant groups.

The approximate ages have been estimated from English standards using height tables by Menzies quoted by Platt (1946).

It is interesting to compare the weights for the different height groups with similar figures for other nationalities. In Table 6 comparison can be made between the Lala figures and those for Northern Rhodesia European children, West Indian children, and London elementary school children. I examined the 72 Northern Rhodesia European children at Broken Hill, Northern Rhodesia; the figures for the West Indian children and the London children were extracted from a table given by Platt (1946). The figures for the sexes have been combined in Table 6.
Both European Rhodesian and Lala children compare very unfavourably with English children. It is interesting to see how close are the mean weights of the European Rhodesian and the Lala groups, the European child in Northern Rhodesia seeming at a considerable disadvantage when

TABLE 6

Comparison of Weights at Different Heights for African, European Rhodesian, West Indian, and ENGlish ChIIDRen (SeXes Combined)

\begin{tabular}{|c|c|c|c|c|}
\hline \multirow[b]{2}{*}{$\begin{array}{c}\text { Height } \\
\text { (in.) }\end{array}$} & \multicolumn{4}{|c|}{ Mean Weight (lb.) } \\
\hline & $\begin{array}{l}\text { North } \\
\text { Rhodesia } \\
\text { Lala } \\
\text { (1948) }\end{array}$ & $\begin{array}{c}\text { North } \\
\text { Rhodesia } \\
\text { European } \\
\text { (1948) }\end{array}$ & $\begin{array}{c}\text { English } \\
\text { (1938) }\end{array}$ & $\begin{array}{l}\text { West } \\
\text { Indies } \\
\text { (1944) }\end{array}$ \\
\hline $\begin{array}{r}45 \cdot 5 \\
-48\end{array}$ & $47 \cdot 0$ & $47 \cdot 7$ & 50 & $47 \cdot 5$ \\
\hline $49-51$ & $54 \cdot 0$ & $52 \cdot 2$ & 64 & 58 \\
\hline $52-54$ & $60 \cdot 6$ & $61 \cdot 7$ & 70 & 60 \\
\hline $55-57$ & $71 \cdot 7$ & & 87 & 75 \\
\hline $58-60$ & $82 \cdot 0$ & & & \\
\hline $61-63$ & 94.5 & & & \\
\hline
\end{tabular}


compared with his English counterpart. The figures for the African and West Indian children are equivocal, with the balance in favour of the West Indies.

Until more is known about birth weights for African communities comparison between weights at different ages for different peoples is not justified, as it has been demonstrated that the weight at any age is dependent on the weight at birth (Illingworth, Harvey, and Shan-Yah Gin, 1949). The low relative figures for the Lala may be due to low birth weights, but this would not account for the discrepancy between the figures for the European children from Rhodesia and from England.

Signs of Malnutrition. Appendix A records the overall results of the survey. For convenience in presentation the children have been divided into 6 in. height groups. Also an attempt has been made to divide the children into three different geographical groups, indicated as N.E., S.W., and V, so that some comparison is possible between different localities.

Locality N.E. is the north-east plateau area, and comprises all the schools on the Serenje plateau except one. The schistosomiasis rate is very low $(5 \%)$. The staple here is finger millet.

Locality S.W. is the south-west plateau area and includes all the schools on the Mkushi plateau together with the Serenje school excluded from locality N.E. The schistosomiasis rate here is high $(49 \%)$, and the staple is kaffir corn. Although this area includes a Serenje school the people living near the school eat as much kaffir corn as millet, owing to the poor woodland, and so can justifiably be included in the kaffir corn group; the determining factor, however, in including this school in locality S.W. was the high incidence of schistosomiasis. The school is indicated on the sketch map by its name, Chipata.

Locality $\mathrm{V}$ is the valley area. This includes the schools which lie in the Luangwa, Lukusashi, and Lunsemfwa valleys. This locality differs from the previous two by climate, altitude, and terrain. The schistosomiasis rate is high $(41 \%)$, and the staple is kaffir corn.

Before proceeding further it must be stressed that the facts in Appendix A refer to an unselected group of children living a normal life in the reserves, the group surveyed being probably a fair representative sample of the Lala school child. The majority of the children were weekly boarders or day scholars. The weekly boarders arrived at school on Sundays with a five-day supply of food which they cooked themselves. At mid-day on Friday they went home to collect a further supply, in many cases the return journey involving a walk of 30 to $\mathbf{4 0}$ miles. The weekly boarders and day children therefore ate the same diet as other children of the area, no food being supplied by the school except for a few vegetables from the school garden in some instances. A small group of 85 boarders ( 60 N.E. and 25 S.W.) were resident during term at two missions, food being supplied by the missions but purchased locally.

Unfortunately owing to the lack of similar studies of children in East and Central Africa it is not possible to compare the figures from this survey with any others. Trowell (1948) and Kekwick and his colleagues (1945) in East Africa, and Platt (1947) in Nyasaland, have carried out nutrition surveys, but these have involved selected groups of males in the case of the first two authors and a mixed group of males, females, and children in the case of Platt.

It is not proposed to follow the customary procedure of listing the signs of malnutrition under the various vitamin deficiency states which are supposed to cause them. No frank case of a vitamin deficiency disease was seen, nor was one expected. What I hope to do is to give a picture of what these children looked like to an observer making a clinical study of the Bantu school child in his natural surroundings.

HAIR. In the great majority of cases the hair was normal. Occasionally it was slightly soft, but hypochromotrichia and straight hair were not seen.

Chenlosis. Some degree of cheilosis was very common and was present in $70 \%$ of all the children. The milder cases were confined to the lower lip but involvement of both lips was seen not infrequently ( $27 \%$ of all cases with cheilosis).

Angular Stomatrits. This was much less common than cheilosis, being recorded in only $3 \%$ of the children. With one exception all cases seen were in locality N.E.

Dyssebacia. Dyssebacia was only seen in N.E. children and was confined to the older age groups.

Naso-labial Seborrhoea. This was very uncommon, and only seen in older children (not recorded in Appendix A).

ENLARged PAROTIDS. An enlarged parotid gland is now considered to be a possible sign of malnutrition and one of the stigmata of malignant malnutrition in the adolescent and adult (Trowell, 1948). A palpable enlargement of the parotid was found in $13 \%$ of all children, usually bilateral but not necessarily so, the gland on one side often being larger than its fellow.

Eye Signs. The general impression was that the eye signs of malnutrition were uncommon; some degree of xerosis conjunctivae, and redundant tissue in the vicinity of the canthi were not uncommon, 
but to what extent these changes were due to irritation by smoke in an unventilated hut rather than to malnutrition, is debatable. Owing to the vagueness of any eye signs that might have been present no records are included in Appendix A. Xerophthalmia and Bitot's spots were not seen.

ToNGUE SIGNS. Enlarged papillae were seen in only $1 \%$ of the children, some degree of atrophy of the tip and sides of the tongue in $17 \%$, and a fissured tongue in $2 \%$. Impressions made by the teeth on the edge and tip of the tongue were seen frequently but in the majority of cases these impressions were smoothed out when the organ was protruded to its full extent. Dental impressions were only recorded when they persisted in the fully protruded tongue, and these were found in $14 \%$ of children.

Pigmentation of the fungiform papillae of the tongue has been dealt with elsewhere (Beet, 1948); it was then concluded that pigmentation of the tongue was not of any apparent value as a clinical sign of malnutrition. Further study has confirmed this opinion. It is possible that a pigmented tongue, far from being a sign of ill health, may be one of relative good health as there is no doubt that, apart from hereditary factors, the blackness of an African's skin depends upon his state of health, hypopigmentation being one of the signs of chronic ill health; this may also apply to the amount of melanin deposited in his tongue. Raper (1948) gives an account of the pathology of tongue pigmentation. The term 'bruised tongue' used in Appendix A refers to the condition in which there is a diffuse bluish patch on the tongue, generally associated with the more superficial pigmentation just considered. Tongue pigment was found in $25 \%$ of all children, less frequently in the valley than on the plateau.

AbNoRmal Gums. The state of the gums was on the whole very bad; loss of the interdental papillae, oedema, and frank gingivitis were common; $38 \%$ of the children were considered to have unhealthy gums, the girls being less frequently affected than the boys.

Dental Caries. Dental caries was recorded in $12 \%$ of subjects; no probe was used and so only the more severe cases were detected.

Xerosis of THE Skin. Some degree of dryness of the skin of the limbs was very common indeed, most marked in the feet, less so in the legs, and least of all in arms and hands; occasionally the skin of the whole body was involved.

Xerosis of the arms and hands was recorded in $92 \%$ of children, the incidence decreasing in the older groups; $99 \%$ had xerosis of the legs and feet. Generalized xerosis was only seen in $2 \%$ and was more frequent in the smaller children, this last condition being confined to boys.
Follicular Keratosis. This was seen in $23 \%$ of the children. As this condition was most frequently observed on the extensor surface of the forearms and the back of the elbows, these parts were examined as a routine in every child; not infrequently the folliculosis was more apparent to the touch than to the sight. It was most frequently found in locality N.E. and was commoner in the bigger children. In several cases the legs were involved and in occasional cases the trunk; most cases were, however, mild and confined to the elbow region.

Hyperkeratosis of Elbows. An excessive thickening of the skin over the olecranon process of the ulna was seen in $20 \%$ of children, and was much more commonly found in boys than girls (Appendix B); the reason for this was not apparent. Hyperkeratosis did not appear to be associated with follicular keratosis.

HYPERKERATOSIS OF KNEES. This was as common as xerosis of the skin, and not infrequently the thickening of the skin over the patella was very marked.

ATROPHY OF THE SKIN. It was only appreciated that atrophy of the skin of the leg below the knee was not uncommon after the survey was well under way, and for this reason it has not been recorded in Appendix A; it probably occurred in about $5 \%$ of children, being characterized by smooth, shiny skin on the anterolateral aspect of the leg (Platt, 1945).

Crackled Skin. As defined by Platt (1945), and later by Trowell (1948), crackled skin was also not infrequently encountered, but for reasons similar to those for atrophy of the skin, it has not been included in Appendix A. Moreover it was found most difficult to decide which children should be considered as having a normal reticulation of the skin of the lower leg and which were definite enough to be classified as crackled skin.

LEG UlCERS. No cases of tropical ulcer were seen: $12 \%$ of the children had large scars on the legs, most frequent in the older age groups of locality N.E.

Tender Calves. Every child was examined for tender calves but no cases were found.

In conclusion it can be stated that these children showed signs of the following deficiencies in their diet. (1) Calories and protein, shown by low weights when related to heights (Tables 5 and 6): (2) vitamin A, shown by abnormalities of the skin such as xerosis, follicular keratosis, hyperkeratosis of elbows and knees, atrophy of the skin, and crackled skin; (3) vitamin C, possibly indicated by follicular keratosis and abnormal gums; (4) vitamin B complex, shown by cheilosis and dental indentations of the tongue; (5) iodine, shown by the 
incidence of enlarged thyroid. These conclusions agree with the findings of the dietary survey carried out on the Serenje plateau.

Other Clinical Signs. We found a number of other clinical signs and these are indicated.

Enlarged ThyroId. Serenie and Mkushi are endemic goitre areas, $38 \%$ of children showing enlargement of the thyroid. As is to be expected the incidence was higher in girls (Appendix B), but this difference is not marked, apart from locality V, because the puberty age group is not well represented.

The Heart. Apical and basal systolic murmurs were heard in $14 \%$ of the children. Only one of these cases was considered to have congenital heart disease; the murmurs in the remainder were presumably of functional origin, but under the conditions in which clinical examinations were conducted it was difficult to be sure that early rheumatic heart disease was not being missed. Of great interest was the location of the apex beat; in several subiects the apex beat was well outside the mid-clavicular line in the fifth intercostal space. Of 205 children in whom the apex beat was accurately located by palpation 29 , or $14 \%$, had apparently enlarged hearts, although not associated with a systolic murmur to a greater degree than would be expected by mere chance. It is considered that these children had not in fact enlarged hearts but that the heart was displaced to the left for some reason, possibly owing to a narrowing of the space between the sternum and vertebral column.

Umbilical Hernia. This was recorded in $3 \%$ of children. This low figure, in spite of the prevalence of umbilical hernia in Bantu babies, confirms Mack's (1945) finding that $90 \%$ of umbilical herniae heal spontaneously. It is probable that this healing takes place between the ages of 2 and 7 years in most cases.

ENLARged Liver. An enlarged liver was present in $5 \%$ of children. It was found most frequently in localities V. and S.W. where it may have been due to schistosomiasis.

Parasites and Sicklaemia. Appendix A shows the incidences for malaria, hookworm infestation, schistosomiasis, and sicklaemia. Any relationship between these conditions and the prevalent anaemia of this group of children has already been considered in detail (Beet, 1949).

\section{Comparison of the Three Localities}

Appendix B shows in greater detail the figures for the two middle groups of Appendix A to demonstrate how the children of the three localities compared. Owing to the uneven distribution of the children in the youngest and eldest groups they have been excluded. The manner in which the localities differed from each other is shown at the head of the table, the three main variables being altitude, and therefore climate, staple diet, and schistosomiasis incidence. Of most interest, from the nutritional aspect, is a comparison of the plateau children from localities N.E. and S.W. One would expect that the children of locality S.W. would have been at a disadvantage owing to the prevalence of schistosomiasis and the higher incidence of hookworm infection. However, it is clear that, apart from a lower height weight ratio for the boys and a lower haemoglobin mean, the children from this locality were healthier than those from locality N.E., as the incidences in both sexes were higher in the latter group for cheilosis, angular stomatitis, dyssebacia, atrophy of tip and sides of the tongue, follicular keratosis, and leg scars. It is thus apparent that the nutritional state of the N.E. children was worse than that of the S.W. group; this may be in part accounted for by the children in the former area having been examined during the period February-June when the season's crop was still in the garden, a time when any food shortage was most liable to occur, and in addition this is the time of the year when seasonal malaria is at its worst. However, these disadvantages should not have offset the disadvantages the S.W. children had to contend with, due to their degree of helminthic infestation, which is reflected in their low haemoglobin values. Moreover, it has been observed in this survey that there is very little seasonal variation in the clinical signs due to malnutrition, although there is probably a marked difference in the amount of weight gained during each of the four quarters of the year.

It would be most rash to draw any final conclusions from this apparent superiority of the S.W. children. It should be noted that the staple of this area is kaffir corn as a result of a compulsory change from finger millet made five to ten years ago. This change of staple was made necessary owing to the devastation of the countryside of the Mkushi district, caused by woodland clearing for millet gardens, and an increasing population. The decision to change the staple would appear to have been a sound one from the nutritional point of view, and there is ground for believing that the inhabitants of the Serenje district would certainly be no worse off if they also were made to change their agricultural habits and grow kaffir corn as a staple instead of finger millet in an effort to preserve the rapidly decreasing forest areas of Serenje. I consider that this step should be taken as an urgent measure. 
With regard to the valley children, they appeared to be very similar to the S.W. children, and it is to be noted that their staple was also kaffir corn and that their schistosomiasis rate was also very high; the environmental differences between these two groups are due to climatic and geographical features which have been considered already.

Pigmentation of the tongue was of lower incidence and haemoglobin values were less than for the S.W. group, but there was a greater prevalence of dental caries, enlarged thyroid amongst the older girls, enlarged spleen and liver, than found on the plateau as a whole. The general impression gained was that children of the lower age groups were in a poorer state of health in the valley than on the plateau although the older groups were similar. This may account for the lower incidence of pigmentation of the tongue observed in the valley children.

\section{Correlation of Physical Signs and Age}

In Table 7 are recorded the conditions which were found to differ significantly in the different height groups. These figures are taken from the N.E. group of children only, as this contained an adequate number of all groups above $48 \mathrm{in}$. in height, including $61 \mathrm{in}$. and over.

From Table 7 it can be seen that the incidence of cheilosis, xerosis of the arms, generalized xerosis, hyperkeratosis of the knees, enlarged spleen, and the malaria parasite rate decreased with age. However, dyssebacia, dental impressions of the

TABLE 7

Clinical Signs at Different Ages*

\begin{tabular}{|c|c|c|c|}
\hline Height group (in.) & $48 \cdot 5-54$ & -60 & Over 60 \\
\hline Total no. in group & 73 & 152 & 68 \\
\hline Cheilosis & $83 \%$ & $76 \%$ & $62 \%$ \\
\hline Dyssebacia & 0 & $3 \%$ & $9 \%$ \\
\hline $\begin{array}{c}\text { Dental impressions on } \\
\text { tongue }\end{array}$ & $8 \%$ & $13 \%$ & $22 \%$ \\
\hline Xerosis of arms & $97 \%$ & $89 \%$ & $69 \%$ \\
\hline Generalized xerosis & $7 \%$ & $2 \%$ & 0 \\
\hline Follicular keratosis & $25 \%$ & $30 \%$ & $37 \%$ \\
\hline Hyperkeratosis knees .. & $99 \%$ & $93 \%$ & $66 \%$ \\
\hline Enlarged spleen & $40 \%$ & $22 \%$ & $15 \%$ \\
\hline Malaria parasites & $66 \%$ & $47 \%$ & $28 \%$ \\
\hline Sicklaemia & $18 \%$ & $11 \%$ & $15 \%$ \\
\hline
\end{tabular}

*N.E. group of children only-both sexes. tongue, and follicular keratosis were found more frequently in the older children.

It is interesting to note that enlargement of the parotid was found at about the same incidence in all the groups with a tendency to increase as age advances; parotid enlargement is included in Table 7 as very little is known about the significance of this condition. The sickle cell trait is also included in the table as a point of general interest.

\section{Summary and Conclusions}

An account is given of the findings of a health survey carried out among the Lala tribe of Northern Rhodesia, preceded by a short description of the country they live in, and the diet on which they subsist.

The results of the survey are recorded in tables, and a brief description is given of the clinical signs found, particularly those connected with malnutrition.

It is concluded that Lala children show clinical evidence of a diet deficient in calories, protein, vitamins $A, B$ complex and $C$, and iodine.

It is considered that kaffir corn is at least as good a staple as finger millet, and that a change from finger millet to kaffir corn is justified in an effort to preserve the forest areas which are doomed to destruction if the cultivation of finger millet on the present system is allowed to continue.

I am indebted to the Director of Medical Services, Northern Rhodesia, for permission to publish this paper.

\section{REFERENCES}

Barakat, M. R., and Smith, A. Dean (1949). Lancet, 2, 12.

Beet, E. A. (1948). E. Afr. med. J., 25, 433.

(1949). Trans. roy. Soc. trop. Med. Hyg., 43, 317.

Kekwick, A., Wright, J., and Roper, A. B. (1945). 'A Study in Nutrition of E.A. Army Native Personnel.' Unpublished Report, Medical Research Laboratory, Nairobi.

Illingworth, R. S., Harvey, C. C., and Shan-Yah Gin (1949). Lancet, 2, 598.

Mack, N. K. (1945). E. Afr. med. J., 22, 369.

Phillips, R. A., Van Slyke, D., Dole, V. P., Emerson, K., Fenetion, P. B., and Archibald, R. M. (1943). - Copper Sulfate Method for Measuring Specific Gravities of Whole Blood and Plasma.' New York. Josiah Macy Junior Foundation.

Platt, B. S. (1945). Brit. med. Bull., 3, 179.

(1946). "Nutrition in the British West Indies.' Colonial No. 195, London, H.M. Stationery Office. (1947). Trans. roy. Soc. trop. med. Hyg., 40, 379.

Raper, A. B. (1948). E. Afr. med. J., 25, 245.

Stephen, J. D. (1948). Trans. roy. Soc. trop. med. Hyg., 41, 829.

Thomson, E. C. (1949). Unpublished report on nutrition survey in Serenje district, Office of Director of Medical Services, Lusaka, Northern Rhodesia.

Trapnell, C. G. (1943). 'The Soils, Vegetation, and Agriculture of North Eastern Rhodesia.' Lusaka Government Printer.

Trowell, H. C. (1948). E. Afr. med. J., 25, 311. 
$-8$

48 and below

Height in inches

Locality

Total number of children examined

Height

Weight 2 mean in

Weight range in $\mathrm{lb}$. Min.

Max.

$$
\text { N.E. }
$$

\begin{abstract}
S.W.
\end{abstract}
$45 \cdot 4$

$47 \cdot 7$

$43 \cdot 5$

$43 \cdot 5$

$61 \cdot 5$

$46 \cdot 5$
$-11$

$-54$

S.W.

56

89

$46 \quad 46 \cdot 1 \quad 46 \cdot 5 \quad 51 \cdot 8 \quad 51 \cdot 6 \quad 51 \cdot 3$

$43 \cdot 5$

$55 \cdot 5$

$58 \cdot 4$

$49 \cdot 5$

$73 \cdot 5$

$56 \cdot 6$

$58 \cdot 9$

$46 \cdot 5$

$46 \cdot 5$

9

$9 \quad 8$

8

61

34

63

Angular stomatitis

Dyssebacia

0

1

Enlarged parotids

Eves:

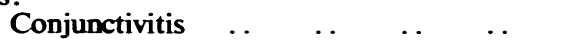

Trachoma

0

Corneal scar

0

0

0

2

$-$

0

0

0

$\frac{0}{4}-\frac{0}{10}$

0

\begin{tabular}{l}
0 \\
\hline 0 \\
\hline 0
\end{tabular}

5
2
2

$\frac{4}{1} \frac{4}{2}-\frac{2}{6}$

\section{Tongue:}

Papillae enlarged

Atrophy tip and sides ...

$\begin{array}{llllllll}\text { Fissures } & . & \ldots & \ldots & \ldots & \ldots & \ldots & 0\end{array}$

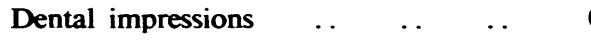

$\begin{array}{lllll}\text { Pigmentation } & \ldots & \ldots & \ldots & \ldots\end{array}$

$\begin{array}{lllllll}\text { Bruising } \ldots & \ldots & \ldots & \ldots & \ldots & 0\end{array}$

Mouth:

Abnormal gums $\quad \ldots \quad$.. $\quad$.

$\begin{array}{lllll}\text { Dental caries } & . & \ldots & \ldots & . .\end{array}$

Thyroid:

Enlargement $\quad \ldots \quad \ldots \quad \ldots$

Skin:

Xerosis arms and hands $\quad . . \quad \ldots \quad$.

Xerosis legs and feet ..

$\begin{array}{llll}\text { Xerosis generalized } & \ldots & \ldots & \ldots\end{array}$

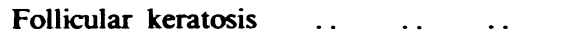

\begin{tabular}{llll} 
Hyperkeratosis elbows .. & $\ldots$ & $\ldots$ \\
\hline
\end{tabular}

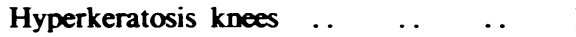

40

3

28

11


D I X A

of 660 Lala School Children*

\begin{tabular}{|c|c|c|c|c|c|c|c|c|c|}
\hline & -14 & & & Over 14 & & & & & \\
\hline & -60 & & & Over 60 & & & TOTALS & & Children \\
\hline N.E. & S.W. & V. & N.E. & S.W. & V. & N.E. & S.W. & V. & \\
\hline 152 & 85 & 85 & 68 & 10 & 13 & 305 & 160 & 195 & 660 \\
\hline 57 & $56 \cdot 8$ & $56 \cdot 4$ & $63 \cdot 7$ & $61 \cdot 8$ & $62 \cdot 2$ & $56 \cdot 8$ & $54 \cdot 7$ & $52 \cdot 0$ & \\
\hline $75 \cdot 2$ & $76 \cdot 5$ & $75 \cdot 8$ & $111 \cdot 1$ & $87 \cdot 0$ & $99 \cdot 8$ & $78 \cdot 0$ & $68 \cdot 6$ & $69 \cdot 0$ & \\
\hline $55 \cdot 5$ & $49 \cdot 5$ & $61 \cdot 5$ & 78 & $64 \cdot 5$ & $82 \cdot 5$ & $43 \cdot 5$ & $43 \cdot 5$ & $43 \cdot 5$ & \\
\hline 133 & $100 \cdot 5$ & $100 \cdot 5$ & 150 & 115 & 120 & $150 \cdot 0$ & $115 \cdot 0$ & 120 & \\
\hline 115 & 48 & 62 & 42 & 2 & 9 & 226 & 93 & 142 & $70 \%$ \\
\hline 9 & 0 & 0 & 2 & 0 & 0 & 16 & 0 & 1 & $3 \%$ \\
\hline 5 & 0 & 0 & 6 & 0 & 0 & 11 & 0 & 0 & $2 \%$ \\
\hline 23 & 11 & 11 & 11 & 0 & 1 & 45 & 15 & 24 & $13 \%$ \\
\hline 0 & 2 & 1 & 0 & 0 & 0 & 5 & 6 & 5 & $2^{\circ} \%$ \\
\hline 7 & 1 & 1 & 0 & 0 & 0 & 9 & 2 & 3 & $2^{\circ} \%$ \\
\hline 1 & 1 & 3 & 0 & 0 & 1 & 3 & 1 & 10 & $2 \%$ \\
\hline 4 & 1 & 1 & 2 & 0 & 0 & 7 & 1 & 1 & $1 \%$ \\
\hline 34 & 9 & 7 & 19 & 0 & 1 & 75 & 19 & 19 & $17 \%$ \\
\hline 2 & 0 & 2 & 2 & 1 & 1 & 5 & 1 & 5 & $2 \%$ \\
\hline 21 & 14 & 11 & 15 & 1 & 5 & 42 & 22 & 31 & $14 \%$ \\
\hline 44 & 27 & 13 & 23 & 2 & $\mathbf{0}$ & 91 & 38 & 33 & $25 \%$ \\
\hline 8 & 2 & 1 & 1 & 0 & 0 & 9 & 4 & 5 & $3 \%$ \\
\hline 58 & 29 & 36 & 32 & 0 & 6 & 115 & 56 & 82 & $38 \%$ \\
\hline 7 & 9 & 10 & 5 & 0 & 1 & 25 & 18 & 35 & $12 \%$ \\
\hline 51 & 26 & 53 & 26 & 2 & 8 & 109 & 39 & 102 & $38 \%$ \\
\hline 135 & 76 & 84 & 47 & 9 & 13 & 263 & 149 & 194 & $92 \%$ \\
\hline 151 & 84 & 85 & 65 & 10 & 13 & 301 & 159 & 195 & $99 \%$ \\
\hline 3 & 2 & 2 & 0 & 0 & 0 & 8 & 3 & 5 & $2 \%$ \\
\hline 45 & 16 & 20 & 25 & 2 & 4 & 89 & 30 & 34 & $23 \%$ \\
\hline 28 & 18 & 11 & 7 & 1 & 2 & 55 & 40 & 39 & $20 \%$ \\
\hline 141 & 81 & 85 & 45 & 7 & 13 & 270 & 152 & 193 & $93 \%$ \\
\hline
\end{tabular}


APPENDIX A-continued

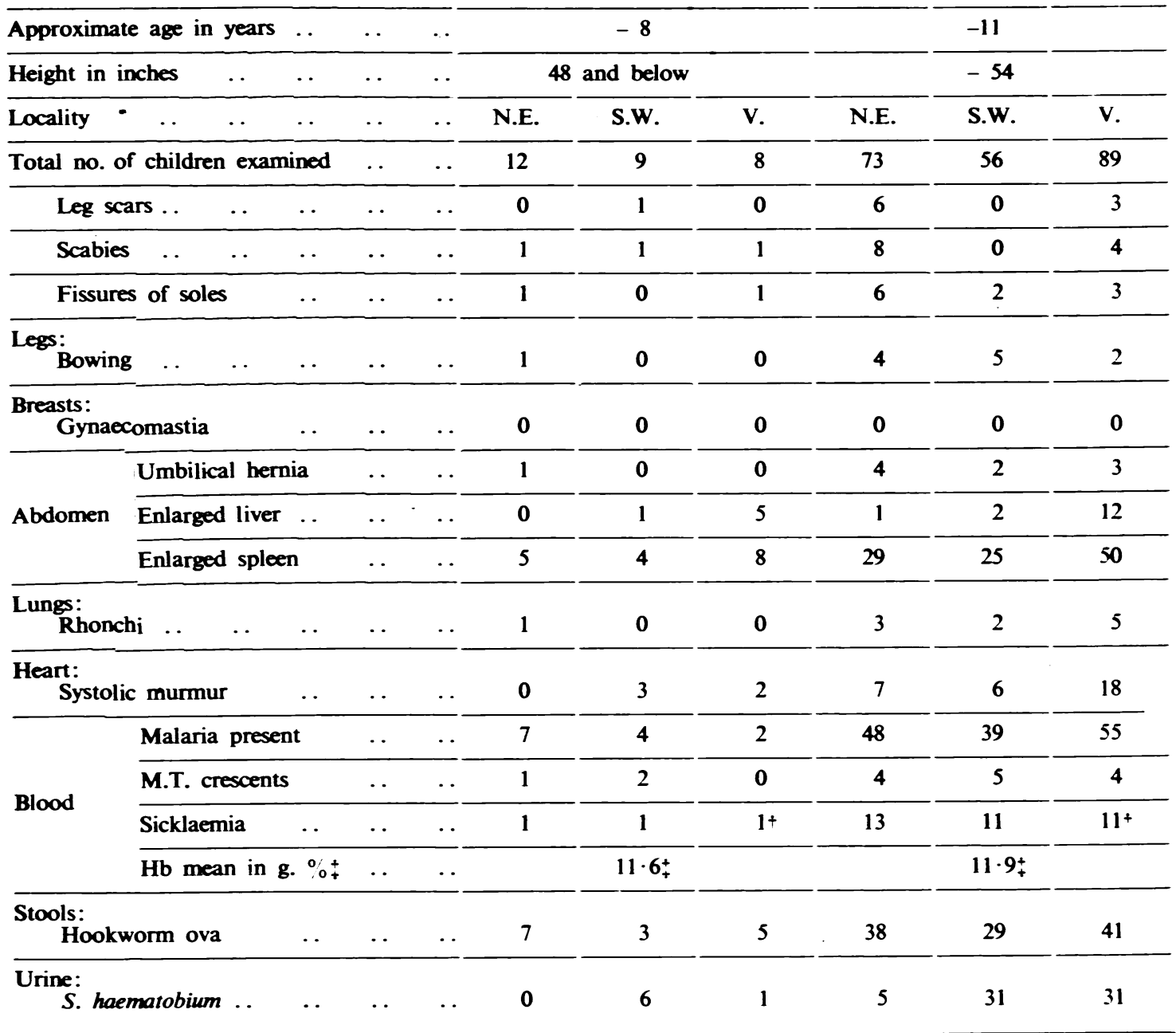

* Male and Female combined.

$\dagger=15$ valley children not examined for sicklaemia-total tested $=645$.

$\ddagger=$ Figures taken from previous paper (630 children). 


\begin{tabular}{|c|c|c|c|c|c|c|c|c|c|}
\hline & -14 & & & Over 14 & & & & & \\
\hline & -60 & & & Over 60 & & & TOtALS & & Children \\
\hline N.E. & S.W. & v. & N.E. & S.W. & v. & N.E. & S.W. & v. & \\
\hline 152 & 85 & 85 & 68 & 10 & 13 & 305 & 160 & 195 & 660 \\
\hline 26 & 8 & 5 & 26 & 1 & 1 & 58 & 10 & 9 & $12 \%$ \\
\hline 17 & 1 & 6 & 15 & 0 & 0 & 41 & 2 & 11 & $8 \%$ \\
\hline 22 & 5 & 7 & 9 & 1 & 0 & 38 & 8 & 11 & $9 \%$ \\
\hline 2 & 3 & 4 & 0 & 0 & 0 & 7 & 8 & 6 & $3 \%$ \\
\hline 2 & 0 & 0 & 2 & 0 & 0 & 4 & 0 & 0 & - \\
\hline 3 & 5 & 3 & 1 & 0 & 0 & 9 & 7 & 6 & $3 \%$ \\
\hline 2 & 6 & 5 & 0 & 0 & 0 & 3 & 9 & 22 & $5 \%$ \\
\hline 33 & 27 & 35 & 10 & 3 & 2 & 77 & 59 & 95 & $35 \%$ \\
\hline 4 & 2 & 12 & 1 & 0 & 1 & 9 & 4 & 18 & $5 \%$ \\
\hline 26 & 5 & 12 & 5 & 1 & 4 & 38 & 15 & 36 & $14 \%$ \\
\hline 71 & 35 & 38 & 19 & 4 & 2 & 145 & 82 & 97 & $49 \%$ \\
\hline 9 & 1 & 1 & 1 & 0 & 1 & 15 & 8 & 6 & $4^{\circ} \%$ \\
\hline \multirow[t]{2}{*}{17} & 10 & $12+$ & 10 & 1 & $1^{+}$ & 41 & 23 & $25 \dagger$ & $14^{\circ} 0^{+}$ \\
\hline & $12 \cdot 4_{+}^{+}$ & & & $13 \cdot 3_{+}^{+}$ & & $12 \cdot 9$ & $12 \cdot 1$ & $11.5_{+}^{+}$ & \\
\hline 68 & 52 & 26 & 28 & 2 & 4 & 141 & 86 & 76 & $46^{\circ} \%$ \\
\hline 4 & 40 & 40 & 5 & 2 & 8 & 14 & 79 & 80 & $26^{\circ}$ 。 \\
\hline
\end{tabular}


Height group (in.)

Locality

Staple diet

Schistosomiasis incidence

Altitude (ft. above sea level)

Sex

Total no. examined .. $\quad \ldots \quad \ldots \quad \ldots \quad 142$

Height (mean in in.)

Height (standard deviation)

Weight (mean in lb.)

Weight (range in lb.) Min.

Max.

Weight/Height ratio (from means)

Face:

$$
\text { Cheilosis of lips }
$$

Angular stomatitis

Dyssebacia

Enlarged parotids

yes:

Conjunctivitis

Trachoma

Corneal scar

Tongue:

Papillae enlarged

Atrophy tip and sides

Fissures

Dental impressions

Pigmentation

Bruising ..

Mouth:

Abnormal gums

Dental caries

Thyroid:

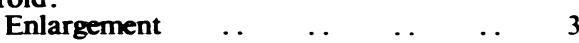

Skin:

Xerosis arms and hands

$2 \cdot 89$

$70 \cdot 0$

$49 \cdot 5$

$97 \cdot 5$

$1 \cdot 28$

$* 80$

8

3

15

2

1

4

24

7

96

N.E.

Finger Millet

$5 \%$

$3,500-5,000$

M. F

$42 \quad 83$

$53 \cdot 9$

2

$-$

18

0

1

11

23

2

43

27
8

\begin{tabular}{|c|c|c|c|}
\hline \multicolumn{2}{|c|}{$49-60$} & & \\
\hline \multicolumn{2}{|c|}{ S.W. } & \multicolumn{2}{|c|}{ v. } \\
\hline \multicolumn{2}{|c|}{ Kaffir corn } & \multicolumn{2}{|c|}{ Kaffir Corn } \\
\hline \multicolumn{2}{|c|}{$49^{\circ}$ 。 } & \multicolumn{2}{|c|}{$41 \%$} \\
\hline \multicolumn{2}{|c|}{$3,500-5,000$} & \multicolumn{2}{|c|}{$1,500-2,500$} \\
\hline $\mathbf{M}$. & F. & M. & $\mathbf{F}$. \\
\hline 87 & 54 & 95 & 79 \\
\hline $54 \cdot 5$ & $55 \cdot 6$ & $52 \cdot 4$ & $54 \cdot 0$ \\
\hline $2 \cdot 82$ & $3 \cdot 06$ & $2 \cdot 76$ & $3 \cdot 12$ \\
\hline $67 \cdot 9$ & $69 \cdot 9$ & $65 \cdot 6$ & $69 \cdot 2$ \\
\hline $52 \cdot 5$ & $46 \cdot 5$ & $46 \cdot 5$ & $49 \cdot 5$ \\
\hline $100 \cdot 5$ & $100 \cdot 5$ & $94 \cdot 5$ & $100 \cdot 5$ \\
\hline $1 \cdot 25$ & $1 \cdot 26$ & $1 \cdot 25$ & $1 \cdot 28$ \\
\hline 60 & 56 & 71 & 73 \\
\hline $\mathbf{0}$ & 0 & 0 & 0 \\
\hline 0 & 0 & 0 & 0 \\
\hline 9 & 13 & 15 & 9 \\
\hline 6 & 2 & 3 & 3 \\
\hline 2 & $\mathbf{0}$ & 1 & 3 \\
\hline 0 & 2 & 5 & 5 \\
\hline 0 & 2 & $\mathbf{0}$ & 1 \\
\hline 13 & 13 & 9 & 10 \\
\hline 0 & 0 & 3 & 0 \\
\hline 20 & 7 & 19 & 10 \\
\hline 31 & 17 & 16 & 20 \\
\hline 3 & 2 & 3 & 1 \\
\hline 47 & 28 & 48 & 37 \\
\hline
\end{tabular}

$49-60$

$$
\text { S.W. }
$$

Kaffir corn

$$
49^{\circ} \text { 。 }
$$

$3,500-5,000$

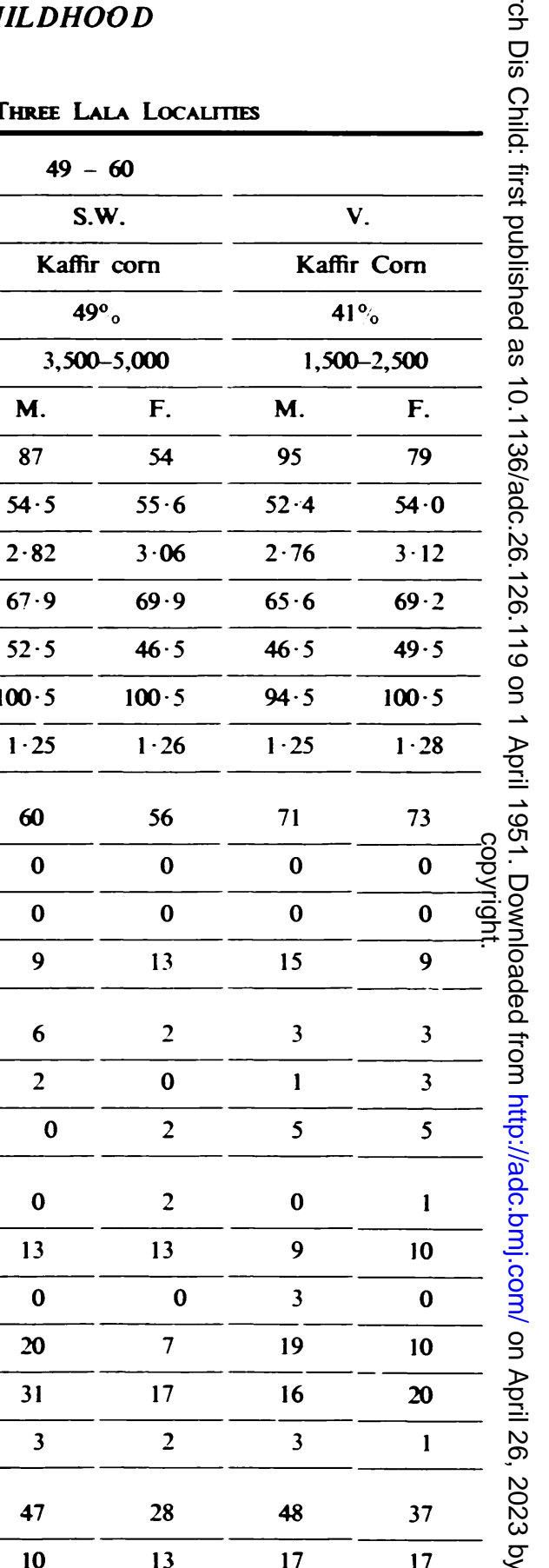

87

$54 \cdot 5$

$2 \cdot 82$

$67 \cdot 9$

$52 \cdot 5$

$100 \cdot 5$

$1 \cdot 25$

60

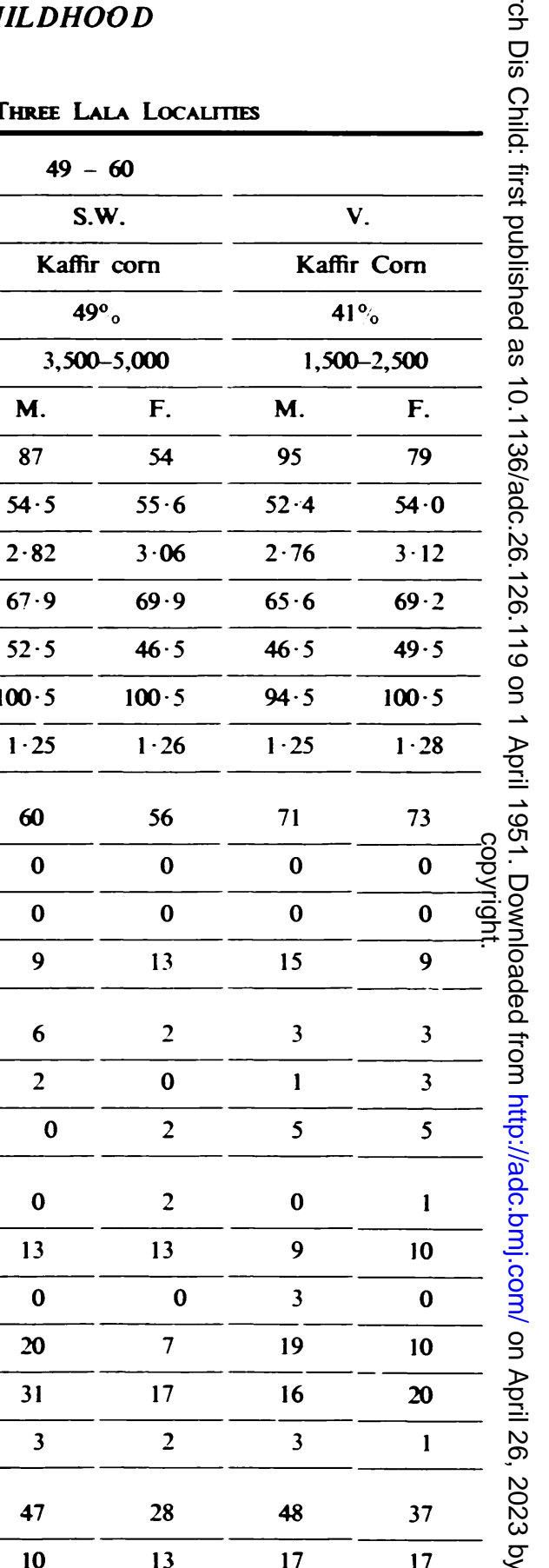

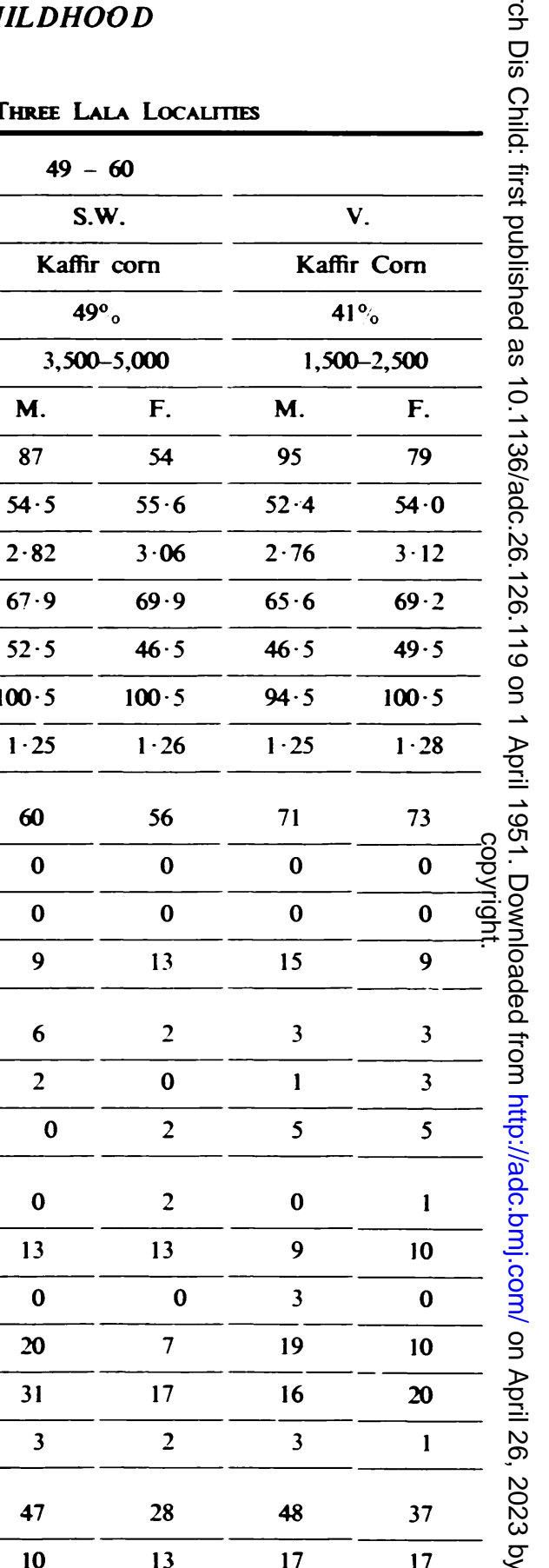

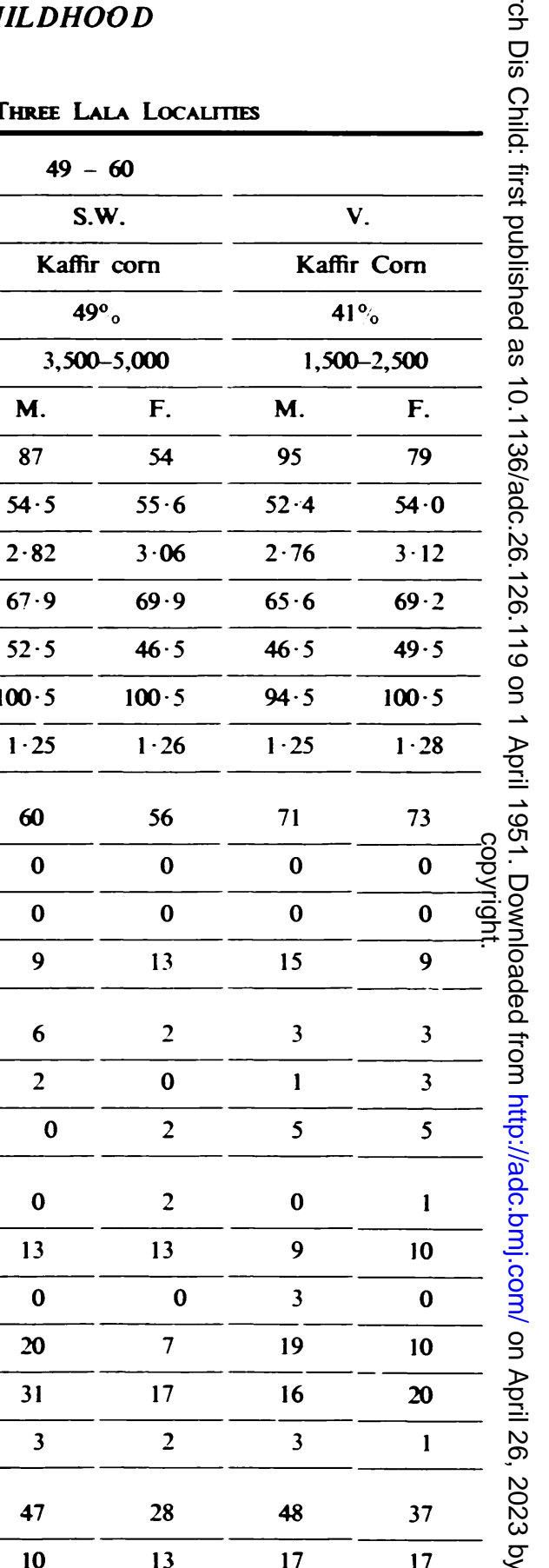

9

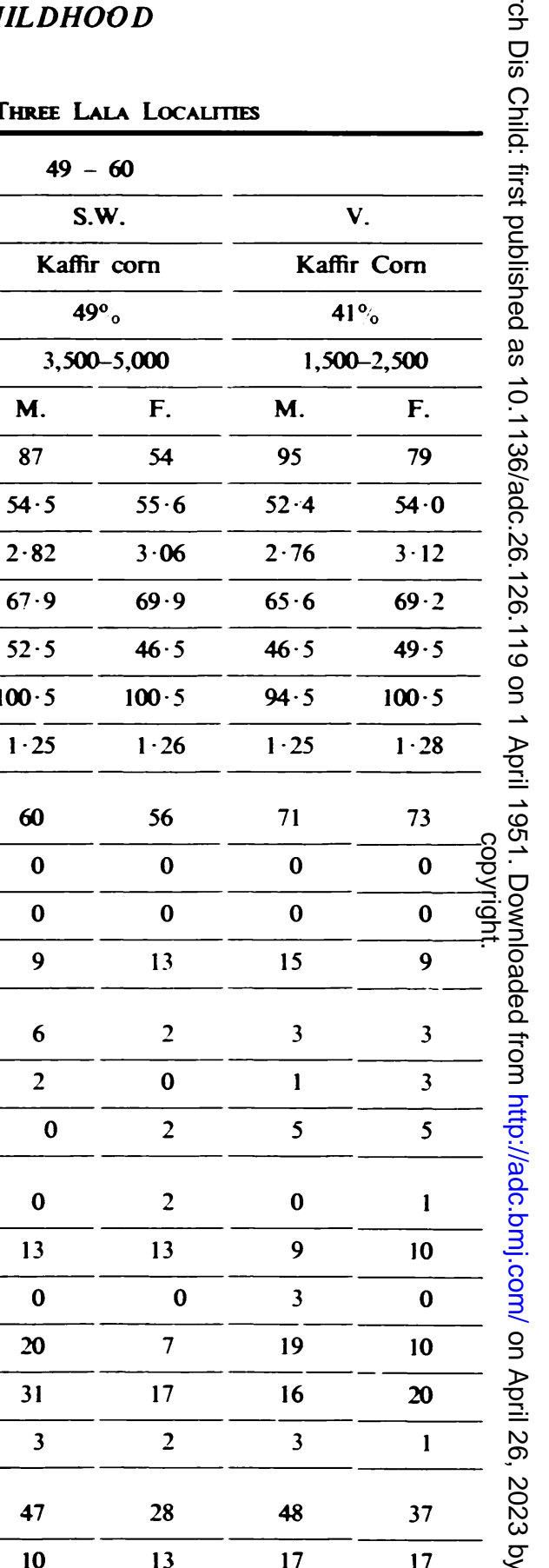

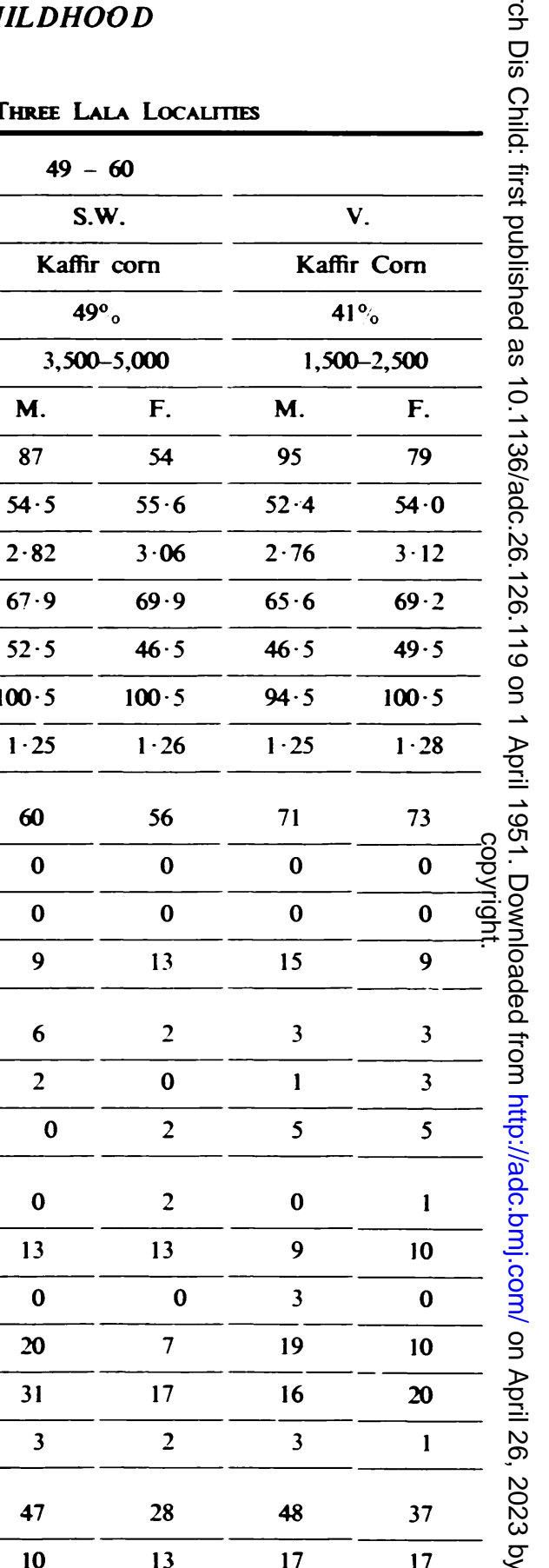

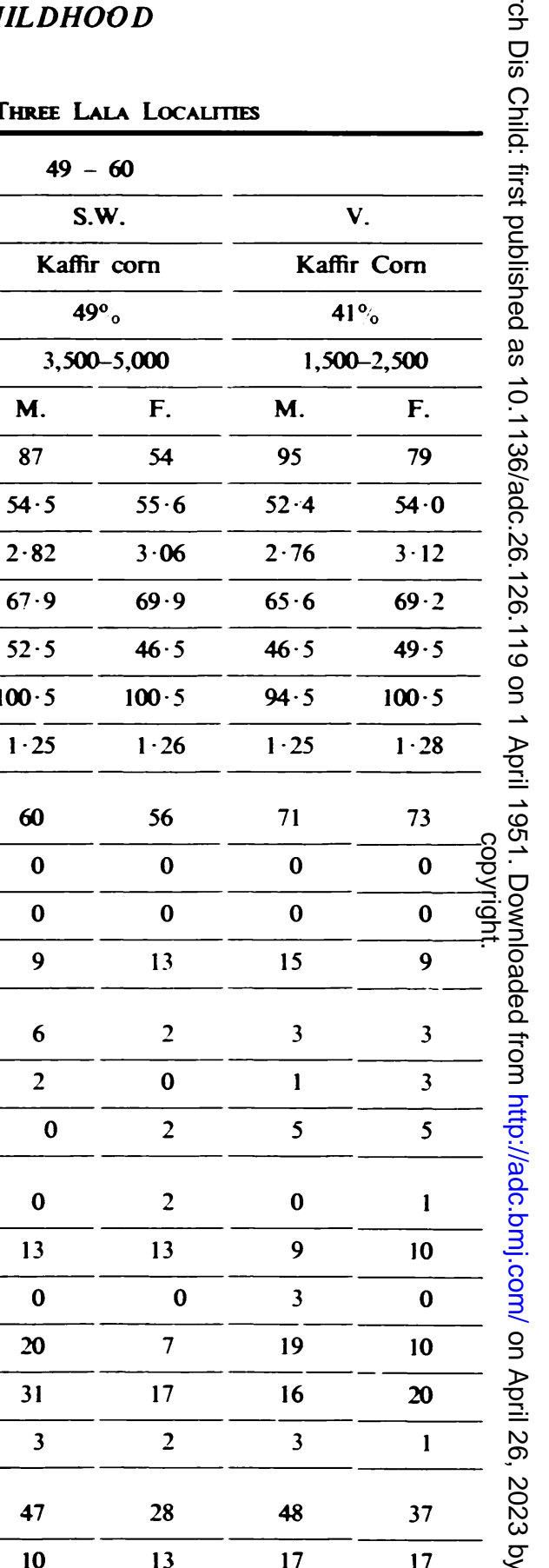

$10-13$

32

41

23

83

94

32

38

70

83

94


APPENDIX B-continued

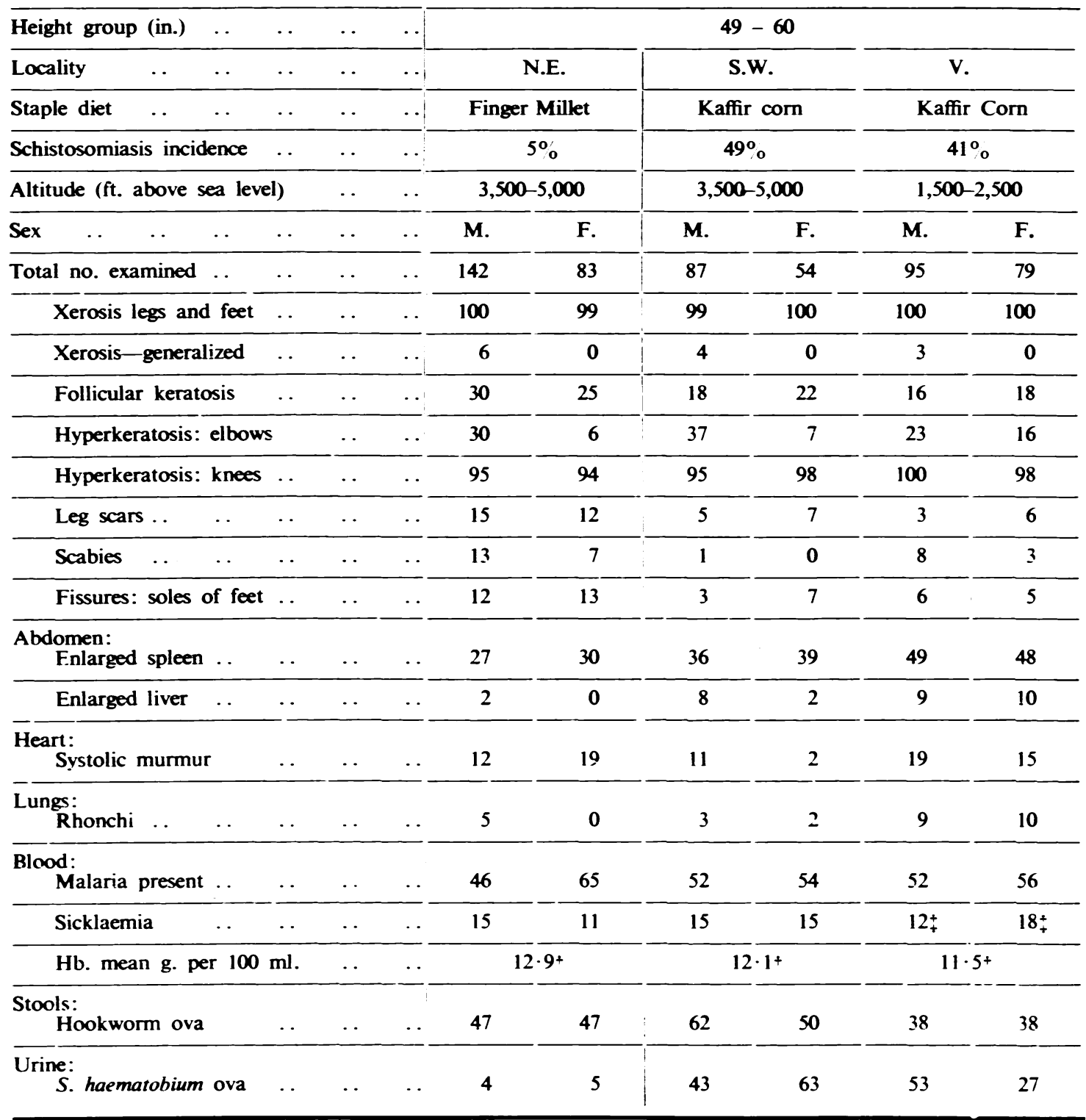

* All figures unless otherwise stated are percentages.

+ These figures are taken from the previous paper and apply to all the 630 children tested and not those actually here specified.

\pm 15 Valley children not examined for sicklaemia. 